\title{
Perilaku Kerja Inovatif pada Karyawan Industri Pariwisata Ditinjau dari Resiliensi
}

\author{
DEVANNY KIREINA DEWI \& DEWI SYARIFAH* \\ Departemen Psikologi Industri dan Organisasi, Fakultas Psikologi Universitas Airlangga
}

\begin{abstract}
ABSTRAK
Industri Pariwisata kini dihadapi dengan lingkungan yang mudah berubah dan kian kompetitif sehingga menunjukkan kebutuhan yang semakin kuat untuk melakukan inovasi. Pada proses inovasi produk atau layanan baru, karyawan dapat menghadapi berbagai tantangan dan masalah sehingga individu memerlukan kapasitas untuk menghadapi situasi tersebut, yaitu resiliensi. Penelitian ini ditujukan untuk mengetahui apakah terdapat hubungan antara resiliensi dengan perilaku kerja inovatif pada karyawan industri pariwisata di Bali. Penelitian kuantitatif ini menggunakan metode survei melalui kuisioner dengan menggunakan skala The Resilience Scale-14 dan skala Innovative Work Behavior. Penelitian terhadap 117 karyawan industri pariwisata di Bali kemudian dianalisis menggunakan uji korelasi dengan teknik Pearson's product moment correlation. Hasil analisis menunjukkan bahwa terdapat hubungan yang signifikan antara resiliensi dengan perilaku kerja inovatif pada karyawan industri pariwisata di Provinsi Bali. Hasil penelitian ini kemudian dapat menjadi panduan bagi industri pariwisata dalam meningkatkan potensi inovatif karyawan, melalui pengembangan kapasitas resiliensinya.
\end{abstract}

Kata kunci: industri pariwisata, perilaku kerja inovatif, resiliensi

\begin{abstract}
Tourism industry currently faced a seasonal changes and increasingly competitive environment, so that is shows a strong need to innovate. In the process of innovating new products or services, employees face various challenges and problems. They need the capacity to deal with these situasions, namely resilience. This research aims to discover the relationship between resilience and innovative work behavior among tourism industry employees in Bali. This quantitative research used survey research type used The Resilience Scale-14 and Innovative Work Behavior Scale as measuring instrument. Correlation analysis 117 tourism employees in Bali was carried out with Pearson's product moment. These results indicate that there is a significant relationship between resilience and innovative work behavior among tourism industry employees in Bali. The results of this study can be a guide for the tourism industry in enhancing employees' innovativeness, through developing their resilience capacity.
\end{abstract}

Keywords: innovative work behavior, resilience, tourism industry 
INSAN Jurnal Psikologi dan Kesehatan Mental, 2018, Vol. 3(2), 83-91, doi: 10.20473/jpkm.v3i22018.83-91 Dikirimkan: 16 Oktober 2019 Diterima: 10 Desember 2019 Diterbitkan: 26 Februari 2020 Editor: Rosatyani Puspita Adiati

*Alamat korespondensi: Fakultas Psikologi Universitas Airlangga, Jalan Airlangga 4-6 Surabaya 60286. Pos-el: dewi.syarifah@psikologi.unair.ac.id

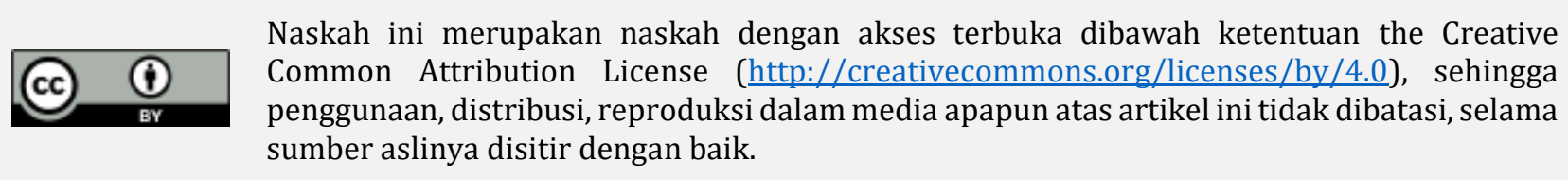

\section{P E N D A H U L U A N}

Setiap tahunnya, industri pariwisata Indonesia menunjukkan adanya pertumbuhan, baik dari segi jumlah kunjungan wisatawannya hingga kontribusinya terhadap devisa negara dan Produk Domestik Bruto (PDB) nasional (Kementerian Pariwisata Republik Indonesia, 2017). Upaya untuk kian pertumbuhan industri pariwisata mulai ditunjukkan dengan semakin meningkatnya penawaran yang dilakukan. Pada bidang usaha perhotelan misalnya, berdasarkan data Smith Travel Research, Inc. (STR) per Oktober 2018, terdapat 22.928 kamar hotel dalam pembangunan di Indonesia, yakni setara dengan 7,4\% dari persediaan kamar yang sudah ada (Smith Travel Research, 2018). Kondisi ini menggambarkan pertumbuhan pasar yang semakin kuat, sekaligus menunjukkan kian kompetitifnya persaingan yang dihadapi dalam industri pariwisata.

Industri pariwisata berada dalam lingkungan kompetitif yang ditandai dengan turbulensi yang tinggi dan perubahan yang cepat (Alsos, Eide, \& Madsen, 2014). Perubahan ini dapat berasal dari lingkungan eksternal yang tidak dapat diprediksi sehingga memungkinkannya industri rentan berada pada posisi yang tidak stabil. Industri pariwisata melibatkan berbagai faktor eksternal yang membuatnya rentan terhadap berbagai krisis yang dapat muncul secara tak terduga seperti krisis ekonomi, politik, terorisme, sosial dan budaya, lingkungan, kesehatan, teknologi, serta krisis komersial (Henderson, 2007). Hal ini dapat mengakibatkan potensi kehilangan kunjungan wisatawan serta hilangnya potensi belanja wisatawan yang akan berkunjung (Kementerian Pariwisata Republik Indonesia, 2017). Untuk itu, industri pariwisata diharapkan segera mempersiapkan destinasi atau variasi layanan alternatif untuk dijadikan daya tarik baru bagi wisatawan untuk tetap berkunjung. Inovasi menjadi penting untuk mendapatkan kembali daya saing dalam siklus ekonomi yang baru tersebut sekaligus merupakan respons terhadap kejadian eksternal yang dinilai sebagai hambatan untuk pertumbuhan berkelanjutan pada industri pariwisata (Alsos, Eide, \& Madsen, 2014).

Berdasarkan hal tersebut, dapat disimpulkan bahwa industri pariwisata saat ini tengah menghadapi persaingan yang semakin kuat. Karakteristik pariwisata yang cenderung mudah mengalami perubahan akibat faktor eksternal memberikan tuntutan yang lebih kuat lagi bagi industri pariwisata untuk berinovasi. Penelitian mengenai inovasi dalam industri perhotelan oleh Iorgulescua \& Ravar (2013), mengkaji mengenai persepsi manajer hotel terkait inovasi dalam organisasinya. Studi ini menyoroti frekuensi dan pentingnya beragam inovasi di industri perhotelan, baik inovasi pada produk dan layanan maupun pemasaran. Penelitian ini menjelaskan bahwa 2 dari 3 manajer percaya bahwa pelanggan akan membayar lebih untuk inovasi layanan yang dilakukan. Hal ini menunjukkan bahwa manajer hotel melihat inovasi sebagai faktor yang penting dalam persaingan industri dan kepuasan pelanggan (Iorgulescua \& Ravar, 2013). 
Dalam industri teknologi dan manufaktur, inovasi dihasilkan terutama melalui bagian Research \& Development (R\&D) atau lingkungan penelitian serupa. Berdasarkan Alsos, Eide, \& Madsen (2014), hanya beberapa industri pariwisata yang memiliki hubungan aktif dengan lembaga penelitian. Industri pariwisata juga didominasi oleh usaha kecil dan menegah yang kurang memiliki prioritas dan kapasitas untuk mendukung kegiatan penelitian dan pengembangan. Kapasitas organisasi untuk mempertahankan kegiatan tersebut memerlukan sumber daya yang cenderung terbatas (Hjalager, 2002). Pada dasarnya, industri pariwisata bersifat dinamis dimana inovasi dalam industri ini seringkali terjadi secara informal yang berasal dari interaksi antar individu dalam industri tersebut. Dalam industri pariwisata, konsumen, pesaing, dan industri pariwisata yang lainnya menjadi sumber informasi yang penting untuk melakukan inovasi. Tingkat dan jenis interaksi yang melibatkan berbagai pihak tersebut dapat bervariasi hingga menciptakan konteks yang lebih kompleks untuk melakukan inovasi (Alsos, Eide, \& Madsen, 2014).

Berdasarkan hal tersebut, kemampuan untuk berinovasi dan memecahkan masalah dalam organisasi bergantung pada seberapa inovatif karyawan dalam industri sebagai pihak yang berhubungan langsung dengan sumber-sumber informasi tersebut. Untuk itu, inovasi dalam industri ini menjadikan sumber daya manusia menjadi faktor penting dalam proses inovasinya. Inovasi pada level individu ini kemudian dikenal dengan perilaku kerja inovatif. Menurut Janssen (2000), perilaku kerja inovatif mengarah pada perilaku kerja yang ditujukan untuk menciptakan, mempromosikan dan menerapkan gagasan, produk, proses dan prosedur baru dalam peran kerja, kelompok kerja, atau organisasi kerja untuk menguntungkan kinerja peran, kelompok atau organisasi itu sendiri (Janssen, 2000).

Inovasi produk atau layanan baru membutuhkan banyak "trial and error" dimana karyawan menghadapi berbagai tantangan dan masalah (Sameer, 2018). Dimulai dari menciptakan, mempromosikan hingga menerapkan ide-ide baru mengarah pada kompleksitas dan dimungkinkan untuk menemui berbagai kendala dalam organisasi sehingga menjadi berisiko dan memungkinkan menyebabkan ketegangan dan konflik. Ketika menciptakan ide, individu mendorong kapabilitas emosi dan kognitifnya untuk mencari, mengidentifikasi ataupun mengkombinasikan informasi untuk mendapatkan ide yang relevan (Amir, 2015). Selanjutnya, ketika mencari dukungan terhadap ide, Potensi akan adanya evaluasi negatif dari atasan maupun rekan kerja dan tekanan untuk menyesuaikan diri dengan pandangan mayoritas menjadi tantangan sendiri bagi individu untuk memperjuangkan idenya (Amir, 2015). Sedangkan, pada implementasi ide tidak hanya banyak pihak dalam organisasi yang akan melaksanakan ide tersebut, tetapi ketersediaan sumber daya untuk mewujudkannya juga menjadi tantangan yang perlu diperhatikan. Untuk itu, setiap tahap dalam perilaku kerja inovatif menunjukkan adanya tantangan dimana individu perlu mampu menghadapinya untuk sukses dengan ide barunya (Amir, 2015).

Melihat situasi yang dihadapi individu dalam proses inovasi, memang tidak hanya organisasi yang perlu membantu untuk mengurangi risiko dan ketegangan yang dihadapi ketika mengajukan dan menerapkan ide yang inovatif, kapasitas individu itu sendiri juga menjadi krusial. Individu memerlukan kapasitas psikologis untuk mengatasi kesulitan dan terus membuat kemajuan dalam menjalankan proses inovasi tersebut (Luthans, Youssef, \& Avolio, 2007). Mengingat individu perlu menghadapi situasi sulit yang tidak diinginkan dengan risiko-risiko yang mungkin muncul selama proses inovasi, resiliensi individu dinilai memiliki peran penting dalam kondisi ini. Resiliensi dinilai dapat menyediakan mekanisme yang dibutuhkan individu untuk dapat bertahan menghadapi tantangan, perubahan dan kebutuhan untuk pemecahan masalah yang berkaitan dengan proses tersebut (Luthans, Youssef, \& Avolio, 2007). Resiliensi merupakan stamina emosional yang digunakan untuk menjelaskan individu yang menunjukkan keberanian dan kemampuan untuk beradaptasi di tengah situasi sulit atau kemalangan yang dialaminya (Wagnild \& Young, 1993). Dengan demikian, hal ini berkaitan dengan pencapaian 
perilaku inovatif pada karyawan, yang seringkali diwarnai dengan risiko dan ketidakpastian hingga dapat menghasilkan tekanan yang signifikan.

Penelitian-penelitian sebelumnya telah meneliti hubungan antara resiliensi dan perilaku inovatif, resiliensi tersebut sebagian besar dikaji sebagai bagian dari modal psikologis. Penelitian yang dilakukan oleh Abbas dan Raja (2015) mengenai hubungan modal psikologis dengan perilaku kerja inovatif pada partisipan yang beragam, yaitu karyawan yang bekerja di bank, kementerian, perusahaan telekomunikasi, dan perusahaan tekstil di Pakistan (Abbas \& Raja, 2015). Penelitian lain pada karyawan non-manajerial di industri manufaktur juga menjelaskan bahwa individu yang lebih resilien menghasilkan motivasi yang kuat untuk mencari cara alternatif mencapai kesuksesan di lingkungan kerjanya, untuk itu mereka cenderung berjuang dan tidak mudah menyerah (Ratnaningsih, Prasetyo, \& Prihatsanti, 2016). Penelitian lainnya juga menunjukkan hasil serupa, Individu yang resilien cenderung lebih inovatif mengingat mereka lebih dapat mengambil risiko dan bersedia menerima perubahan (Sameer, 2018). Selain itu, penelitian lainnya meneliti resiliensi dan perilaku inovatif, dimana penelitian ini menjelaskan bahwa individu resilien memiliki persistensi atau kegigihan serta emosi yang positif lebih sehingga cenderung menampilkan perilaku inovatif (Amir, 2015). Meskipun begitu, belum terdapat penelitian yang berfokus pada konteks industri layanan seperti pariwisata.

Berdasarkan penjelasan tersebut, masih belum terdapat penelitian yang mengkaji hubungan resiliensi dengan perilaku kerja inovatif yang kemudian berfokus pada konteks industri pariwisata. Disamping itu, kondisi pariwisata yang kian kompetitif dengan karakteristiknya yang rentan dipengaruhi oleh kondisi lingkungan eksternal menunjukkan kebutuhan untuk mengkaji faktor yang berkaitan dengan perilaku kerja inovatif karyawannya, termasuk dalam hal ini adalah resiliensi. Konteks pariwisata yang dalam hal ini dinilai memiliki kompleksitas proses maupun tantangan yang berbeda untuk menampilkan perilaku kerja inovatif dibandingkan industri. Untuk itu, penelitian ini kemudian ditujukan untuk meneliti lebih lanjut mengenai ada tidaknya hubungan antara resiliensi dengan perilaku kerja inovatif pada karyawan industri pariwisata.

\section{MET ODE}

\section{Desain Penelitian}

Penelitian ini menggunakan pendekatan kuantitatif dengan desain penelitian survei secara online. Data penelitian dikumpulkan menggunakan instrumen skala psikologis sesuai dengan variabel yang diukur, yaitu resiliensi sebagai variabel bebas dan perilaku kerja inovatif sebagai variabel terikat. Sebelum menyatakan berpartisipasi, partisipan penelitian diminta kesediaannya dengan menyetujui informed consent yang tercantum pada form survei online.

\section{Partisipan}

Penelitian ini menggunakan teknik purposive sampling untuk memilih partisipan. Partisipan pada penelitian ini adalah karyawan industri pariwisata di Provinsi Bali yang telah bekerja selama minimal satu tahun. Jumlah partisipan sebanyak 120 orang, dengan 117 partisipan yang kemudian dapat dianalisis, yaitu karyawan industri pariwisata pada bidang usaha perhotelan (78 orang), kuliner (8 orang), souvenir ( 4 orang), tempat wisata (23 orang), dan transportasi (4 orang). Partisipan laki-laki berjumlah 62 orang dan partisipan perempuan berjumlah 55 orang.

Ditinjau dari segi usia, sebanyak 26 orang berusia 19-25 tahun, 33 orang berusia 26-35 tahun, 20 orang berusia 36-45 tahun dan 38 orang berusia 46-55 tahun. Berdasarkan tingkat pendidikan, sebanyak 41 orang berpendidikan S1 atau diatasnya, 48 orang berpendidikan D1/D3 dan 28 orang berpendidikan INSAN Jurnal Psikologi dan Kesehatan Mental Tahun 2018, Vol. 3(2), 83-91 doi: $10.20473 /$ jpkm.v3i22018.83-91 
SMA. Berdasarkan masa kerjanya, sebanyak 49 orang memiliki masa kerja 1-5 tahun, 20 orang memiliki masa kerja 6-10 tahun, 8 orang memiliki masa kerja 11-15 tahun, 13 orang memiliki masa kerja 16-20 tahun dan sebanyak 27 orang memiliki masa kerja lebih dari 20 tahun.

\section{Pengukuran}

Penelitian ini menggunakan alat ukur berupa kuisioner yang berisi identitas dan data demografis (jenis kelamin, usia, tingkat pendidikan, masa kerja dan bidang usaha) serta dua skala likert untuk mengukur resiliensi dan perilaku kerja inovatif. Resiliensi diukur menggunakan The Resilience Scale-14 (RS-14) yang dikembangkan oleh Wagnild (2009). Instrumen ini terdiri dari 14 aitem, dimana semakin tinggi total skor maka semakin resilien individu tersebut (Wagnild, 2009). The Resilience Scale-14 (RS-14) yang telah ditranslasi dalam Bahasa Indonesia ini peneliti dapatkan langsung dari Gail Wagnild dan tidak ada perubahan yang dilakukan peneliti terhadap instrumen tersebut. Respons pada instrumen ini menggunakan tujuh pilihan jawaban dari rentang 1 (sangat tidak setuju) hingga 7 (sangat setuju).

Perilaku kerja inovatif diukur menggunakan skala Innovative Work Behavior oleh Janssen (2000) yang terdiri dari 9 aitem yang terbagi dalam generasi ide, promosi ide dan realisasi ide. Semakin tinggi total skor pada 9 aitem tersebut, maka semakin inovatif individu tersebut (Janssen, 2000). Instrumen ini menggunakan skala likert dengan rentang 1 hingga 7, dimana nilai 1 mewakili "tidak pernah" dan nilai 7 mewakili "selalu". Instrumen ini telah melalui uji validitas, yaitu content validity melalui penilaian dari professional judgement. Kedua instrumen pada penelitian ini juga telah diuji reliabilitasnya melalui teknik Alpha Cronbach, dimana resiliensi dan perilaku kerja inovatif masing-masing memiliki koefisien reliabilitas sebesar 0,827 dan 0,922 .

\section{Analisis Data}

Data penelitian dianalisis uji korelasi dengan teknik korelasi parametrik Pearson's product moment yang diawali dengan melakukan uji asumsi berupa uji normalitas dan uji linearitas. Analisis dilakukan dengan menggunakan program SPSS 22.0 for Windows.

\section{HAS I L P E N EL I T IAN}

Tabel 1. Hasil Analisis Deskriptif

\begin{tabular}{lcc}
\hline & Resiliensi & Perilaku Kerja Inovatif \\
\hline $\mathrm{N}$ & 117 & 117 \\
Nilai Minimum & 61 & 34 \\
Nilai Maksimum & 98 & 63 \\
Range & 37 & 29 \\
Mean & 83.99 & 51.73 \\
Standar Deviasi & 8.413 & 7.425 \\
Skewness & -0.454 & -0.171 \\
Kurtosis & -0.338 & -0.616 \\
\hline
\end{tabular}

Berdasarkan data analisis deskriptif tersebut, diketahui bahwa data yang dapat diolah dalam penelitian ini berjumlah 117 partisipan. Resiliensi memiliki nilai rata-rata 83.99 dengan nilai minimum sebesar 61 dan nilai maksimum sebesar 98, sehingga terdapat range sebesar 37. Resiliensi memiliki nilai 8.413 yang menunjukkan banyak partisipan yang memiliki nilai resiliensi yang mendekati rata-rata. Variabel

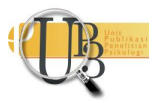


perilaku kerja inovatif memiliki nilai rata-rata sebesar 51.73 dengan nilai minimum sebesar 34 dan nilai maksimum sebesar 63, sehingga terdapat range sebesar 29. Nilai standar deviasi perilaku kerja inovatif sebesar 7.425 sehingga terdapat banyak partisipan yang memiliki nilai perilaku kerja inovatif yang mendekati rata-rata. Nilai skewness resiliensi adalah sebesar - 0.454 dan nilai skewness perilaku kerja inovatif sebesar -0.171 . Hal ini menunjukkan nilai skewness yang negatif sehingga skor partisipan pada kedua variabel dalam penelitian ini berada di sisi kanan dalam persebaran distribusi nilai. Nilai kurtosis pada variabel resiliensi dan perilaku kerja inovatif pada penelitian ini, masing-masing sebesar -0.338 dan -0.616. Hal ini berarti kedua variabel dalam penelitian ini memiliki nilai kurtosis di bawah nilai 0 sehingga distribusi data cenderung datar.

Berdasarkan hasil uji normalitas dengan teknik Kolmogorov-Smirnov, diketahui bahwa resiliensi memiliki distribusi normal ( $p=.080)$. Begitu pula dengan variabel perilaku kerja inovatif yang distribusi normal karena nilai signifikansinya diatas $0.05(p=.096)$. Sedangkan hasil linearitas pada penelitian ini diketahui bahwa hubungan resiliensi dan perilaku kerja inovatif dikatakan linear $(p=0.000)$

Berdasarkan hasil analisis uji korelasi, dapat diketahui bahwa terdapat hubungan yang kuat dan signifikan antara resiliensi dengan perilaku kerja inovatif $(r(117)=0.581, p=0.000)$. Hal ini menunjukkan bahwa kedua variabel dalam penelitian ini memiliki arah hubungan yang positif, dimana semakin tinggi tingkat resiliensi individu maka semakin inovatif individu tersebut, begitu pula sebaliknya. Berdasarkan kekuatan hubungannya, kedua variabel ini memiliki kekuatan hubungan yang tergolong kuat, mengingat nilai koefisien korelasi yang berada diantara 0.50 hingga 1.

\section{I S K U S I}

Penelitian ini menemukan bahwa terdapat hubungan yang kuat dan signifikan antara resiliensi dan perilaku kerja inovatif dengan arah hubungan yang positif. Hal ini menunjukkan bahwa semakin tinggi tingkat resiliensi individu maka semakin inovatif individu tersebut. Hasil penelitian ini mendukung penelitian-penelitian sebelumnya. Penelitian pada karyawan non-manajerial di industri manufaktur menjelaskan bahwa individu yang lebih resilien menghasilkan motivasi yang kuat untuk mencari cara alternatif mencapai kesuksesan di lingkungan kerjanya, untuk itu mereka cenderung berjuang dan tidak mudah menyerah (Ratnaningsih, Prasetyo, \& Prihatsanti, 2016). Penelitian lainnya menjelaskan bahwa individu yang resilien cenderung lebih inovatif mengingat mereka lebih dapat mengambil risiko dan bersedia menerima perubahan (Sameer, 2018).

Kontribusi penting resiliensi adalah pada pandangan yang spesifik mengenai penanganan risiko dan ketidakpastian yang melekat pada proses inovasi. Inovasi produk atau layanan yang baru merupakan proses yang memerlukan banyak percobaan dimana individu menghadapi masalah dan tantangan (Sameer, 2018). Di sisi lain, resiliensi dicirikan dengan respons yang adaptif dalam menghadapi kegagalan atau pun kesuksesan. Ketika menghadapi situasi sulit atau menantang di lingkungan kerjanya, individu yang resilien dapat bangkit kembali dari situasi tersebut dan bahkan melebihi kondisi saat ini dengan menggunakannya sebagai batu loncatan guna mencapai kemajuan yang baru hingga menunjukkan kinerja yang lebih baik (Youssef \& Luthans, 2007). Berdasarkan kaitan ini, dapat disimpulkan bahwa individu yang lebih resilien cenderung lebih inovatif karena mereka lebih dimungkinkan untuk mengambil risiko dan lebih bersedia untuk menerima perubahan (Sameer, 2018). Mengingat individu yang resilien memiliki kapasitas yang lebih besar untuk mengambil risiko, mereka dapat beradaptasi teradap perubahan dan utamanya mencari pengalaman baru dalam hal perubahan dan ketidakpastian tersebut (Youssef \& Luthans, 2007). Individu yang fleksibel ini, ketika berhadapan dengan kesulitan, kegagalan maupun peluang cenderung akan mengembangkan cara-cara baru dalam menghadapinya (Fredrickson, 2001).

INSAN Jurnal Psikologi dan Kesehatan Mental Tahun 2018, Vol. 3(2), 83-91 doi: 10.20473/jpkm.v3i22018.83-91 
Hasil pada penelitian ini juga didukung oleh penelitian yang menemukan bahwa kemampuan resiliensi individu menentukan kinerja inovatif individu tersebut di masa mendatang (Moenkemeyer, Hoegl, \& Weiss, 2012). Dalam hal ini, kegagalan atau peristiwa negatif dari suatu projek inovasi sebelumnya dapat dilihat sebagai pengalaman traumatis yang mewakili inti dari konsep resiliensi. Setelah mengalami kegagalan demikian, individu perlu secara positif menyesuaikan atau bahkan berkembang lebih dari kondisi sebelumnya untuk kemudian dapat menjalani projek inovasi selanjutnya. Untuk itu, penelitian ini menemukan bahwa resiliensi memengaruhi potensi inovatif individu di masa mendatang termasuk dalam menghadapi kesulitan yang mungkin terjadi pada projek inovasi di masa depan (Moenkemeyer, Hoegl, \& Weiss, 2012).

Hubungan kedua variabel ini juga dapat dilihat melalui resiliensi itu sendiri yang mengakui perlunya mengambil tindakan proaktif dan reaktif dalam menghadapi kesulitan (Youssef \& Luthans, 2007), yang mana dapat ditemui dalam proses inovasi yang identik dengan risiko dan ketidakpastian. Secara reaktif, individu yang resilien melihat potensi dimana peristiwa negatif dapat memiliki dampak yang merusak dan karenanya perlu kemampuan untuk bangkit kembali. Kapasitas untuk resilien mengakibatkan individu mengakui dampak yang mungkin terjadi dalam melakukan inovasi dan memungkinkannya yang untuk bangkit kembali pada titik seimbangnya dan kembali berfungsi secara normal (Youssef \& Luthans, 2007).

Resiliensi sebagai suatu kemampuan untuk beradaptasi terhadap kondisi sulit yang dihadapi, dimana individu mampu mengidentifikasi peristiwa negatif tersebut dan menilai secara realistis kapasitasnya untuk bertindak dan menyelesaikan masalah secara efektif (Wagnild \& Young, 1993). Kemampuan untuk bangkit kembali muncul melalui penilaian yang positif terhadap risiko dan sumber daya personal yang dimiliki individu tersebut. Penilaian yang positif ini berkontribusi pada kemampuan individu untuk mencapai regulasi emosi yang efisien dengan menemukan makna positif dalam keadaan negatif (Tugade \& Fredrickson, 2004), sehingga demikian individu dapat menangani situasi sulit yang mungkin dihadapi dalam proses inovasi.

Secara proaktif, resiliensi memungkinkan individu untuk menggunakan halangan yang diterimanya sebagai peluang untuk berkembang bahkan melebihi titik seimbang tersebut. Jadi, individu yang resilien menempatkan nilai positif terhadap faktor risiko yang sebaliknya dapat dianggap sebagai ancaman yang mengurangi kemungkinan untuk hasil yang positif (Youssef \& Luthans, 2007). Ketika individu menunjukkan respons yang resilien pada situasi yang sulit, mereka menginterpretasikan ancaman tersebut sebagai tantangan. Mereka merasa bahwa mereka memiliki akses lebih banyak pada sumber daya daripada tuntutan dari situasi tersebut (Richtner \& Sodergren, 2008). Dalam hal inovasi, hal ini dapat diartikan bahwa individu memiliki keyakinan diri bahwa mereka memiliki asset yang cukup sehingga mereka dapat berkembang melalui situasi sulit dalam proses inovasi tersebut. Sebaliknya, individu yang kurang resilien merasa situasi sulit sebagai ancaman berat, dimana sumber daya yang dimiliki dianggap tidak memadai dibandingkan tuntutan dari situasi tersebut (Richtner \& Sodergren, 2008), sehingga dalam hal ini individu yang kurang resilien tidak memiliki keyakinan akan kemampuan dirinya sehingga dinilai tidak berjuang sepenuhnya untuk menampikan perilaku inovatif secara efektif.

Individu yang resilien dijelaskan merasakan emosi positif yang kuat pula (Fredrickson, 2001). Emosi positif ini membantu mereka untuk menciptakan lingkungan yang suportif yang memfasilitasi perilaku inovatif. Resiliensi menggunakan emosi positif untuk memperluas pikiran dan tindakannya dimana individu tersebut terbuka akan kemungkinan atau peluang-peluang lainnya sehingga meningkatkan potensi untuk menampilkan perilaku inovatif. Karyawan yang memiliki pikiran yang positif ini tidak hanya mampu menemukan ide, tetapi juga memperoleh dukungan dari rekan kerja dan mentransformasikannya ke dalam aplikasi yang bermanfaat (Abbas \& Raja, 2015). 


\section{S I M P U L A N}

Berdasarkan hasil analisis data pada penelitian ini, diketahui bahwa terdapat hubungan positif yang kuat antara resiliensi dengan perilaku kerja inovatif pada karyawan industri pariwisata di Provinsi Bali. Hal ini menunjukkan bahwa semakin tinggi tingkat resiliensi individu maka semakin inovatif individu tersebut, begitu pula sebaliknya. Untuk itu, dapat disimpulkan bahwa hipotesis alternatif (Ha) diterima dan hipotesis null (H0) ditolak. Penelitian ini mengukur perilaku kerja inovatif melalui self-report dari responden. Penelitian selanjutnya kemudian dapat mempertimbangkan untuk menggunakan double source rating dalam hal ini dengan menambahkan supervisor-report dimana perilaku kerja inovatif responden dinilai oleh atasan langsung mereka. Menggunakan dua sumber ini untuk mengukur perilaku kerja inovatif akan mengurangi bias social desirability pada data responden.

Hasil penelitian ini kemudian dapat menjadi bahan pertimbangan bagi organisasi dalam industri pariwisata untuk melakukan pengembangan resiliensi karyawannya yang dapat dilakukan melalui training, coaching, termasuk team-based sessions. Dalam sesi kelompok, pemimpin dalam suatu tim kerja dapat memberikan gambaran resiliensi, setiap karyawan bisa mendapatkan profil resiliensi mereka masing-masing untuk kemudian digunakan di dalam tim untuk memfasilitasi mereka melakukan evaluasi diri hingga kemudian dapat menjadi pembimbing satu sama lain dalam tim untuk mengembangkan action plans mereka terkait evaluasi tersebut. Hal ini kemudian membantu setiap karyawan untuk dapat lebih memahami tingkat resiliensi mereka, memahami bagaimana tim berjalan ketika terjadi perubahan atau kesulitan dan mengembangkan peluang untuk anggota tim untuk membantu sama lainnya dalam mengembangkan tingkat resiliensinya (Varagona \& Hoopes, 2012).

\section{U C A P A N T E R I MAKASIH}

Penulis berterimakasih kepada setiap karyawan industri pariwisata di Bali yang bersedia menjadi responden dalam penelitian ini sehingga penelitian dapat terselesaikan dengan baik.

\section{DEKLARASI POTENSI TERJADINYA KONFLIK KEPENTINGAN}

Devanny Kireina Dewi dan Dewi Syarifah tidak bekerja, menjadi konsultan, memiliki saham, atau menerima dana dari perusahaan atau organisasi mana pun yang akan mengambil untung dari naskah ini, dan telah mengungkapkan bahwa ia tidak memiliki afiliasi selain yang telah disebut di atas.

\section{PUSTAKA ACUAN}

Abbas, M., \& Raja, U. (2015). Impact of psychological capital on innovative performance and job stress. Canadian Journal of Administrative Sciences, 1-11. doi:10.1002/CJAS.1314

Alsos, G. A., Eide, D., \& Madsen, E. L. (2014). Handbook of research on innnovation in tourism industries. Massachusetts: Edward Elgar Publishing, Inc.

Amir, M. T. (2015). Validation of innovative behavior as a multidimensional construct. Jurnal Manajemen Teknologi, Vol. 14, No. 1, 66-80. doi:http://dx.doi.org/10.12695/jmt.2015.14.1.5

Fredrickson, B. L. (2001). The role of positive emotions in positive psychology: The broaden-and-build theory of positive emotions. American Psychologist, Vol. 53, No. 3, 218-226. doi:http://dx.doi.org/10.1037/0003-066X.56.3.218

Henderson, J. C. (2007). Tourism crises: causes, consequences and management. USA: Elsevier Inc.

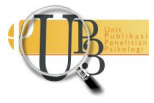


Hjalager, A. M. (2002). Repairing innovation defectiveness in tourism. Tourism Management, 23 (5), 465474. doi:https://doi.org/10.1016/S0261-5177(02)00013-4

Iorgulescua, M.-C., \& Ravar, A. S. (2013). Measuring manager's perception of innovation in the romanian hospitality industry. Procedia Economics and Finance 6, 512-522. doi:https://doi.org/10.1016/S2212-5671(13)00169-X

Janssen, O. (2000). Job demands, perceptions of effort-reward fairness and innovative work behaviour. Journal of Occupational and Organizational Psycholog73, 287-302y, 73, 287-302. doi:https://doi.org/10.1348/096317900167038

Kementrian Pariwisata Republik Indonesia. (2017). Laporan Akuntabilitas Kinerja Kementrian Pariwisata Tahun 2017. Jakarta: Kementrian Pariwisata Republik Indonesia.

Luthans, F., Youssef, C. M., \& Avolio, B. J. (2007). Psychological capital: Developing the human competitive edge. New York: Oxford University Press. doi:10.1093/acprof:oso/9780195187526.001.0001

Moenkemeyer, G., Hoegl, M., \& Weiss, M. (2012). Innovator resilience potential: A process perspective of individual resilience as influenced by innovation project termination. Human Relations, 65(5), 627-655. doi:10.1177/0018726711431350

Ratnaningsih, I. Z., Prasetyo, A. R., \& Prihatsanti, U. (2016). Predicting innovative behavior among employees in a manufacturing company: The role of psychological capital. Anima Indonesian Psychological Journal, Vol. 31, No. 2, 84-90.

Richtner, A., \& Sodergren, B. (2008). Innovation projects need resilience. International Journal of Technology Intelligence and Planning, Vol. 4, No. 3, 257-275. doi:10.1504/IJTIP.2008.020097

Sameer, Y. M. (2018). Innovative behavior and psychological capital: Does positivity make any difference? Journal of Economics and Management, Vol. 32 (2), 75-101. doi:10.22367/jem.2018.32.06

Smith Travel Research. (2018, November 15). Retrieved from https://www.str.com: https://www.str.com/news/media/press-releases

Tugade, M. M., \& Fredrickson, B. L. (2004). Resilient Individuals Use Positive Emotions to Bounce Back From Negative Emotional Experiences. Journal of Personality and Social Psychology, Vol. 86, No. $2,320-333$.

Varagona, L., \& Hoopes, L. (2012). The community resilience profile: A framework for assessing community development efforts. In V. Pulla, A. Shatte, \& S. Warren, Perspectives on Coping and Resilience (pp. 307-332). New Dehli: Authorspress Global Network.

Wagnild, G. (2009). The resilience scale user's guide for the US english version of the resilience scale and the 14-item resilience scale (RS-14). Worden, MT: The Resilience Scale.

Wagnild, G. M., \& Young, H. M. (1993). Development and Psychometric Evaluation of the Resilience Scale. Journal of Nursing Measurement, Vol. 1, No. 2, 165-178.

Youssef, C. M., \& Luthans, F. (2007). Positive Organizational Behavior in the Workplace: The Impact of Hope, Optimism, and Resilience. Journal of Management, Vol. 33, No. 5, 774-800. doi:10.1177/0149206307305562

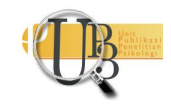

